\title{
Relationship of Bioethics in Albania and Traditional Islamic Teaching
}

\author{
Bardhyl Çipi
}

\section{Introduction}

At present, all countries consider the human health one of the highest values respecting human rights, dignity and individuality (1). In this framework, where Bioethical opinion gets an important place, it is necessary to know the influence of traditional Islamic teaching in Bioethical practice, especially in our country, because the majority of Albanian people practice this religion.

Issues of medical ethics, medical deontology, and bioethics have been studied extensively as means to improve health care in Albania. When it comes to ethical concerns, people often turn to religious or deontological norms and values to answer difficult questions.

In fact, about $90 \%$ of world population finds religion to be a more important source of guidance in life than science (10).

Based on these arguments, different issues of Albanian bioethics are analyzed from an Islamic point of view since most of the population in Albania affiliates with Islam.

There is a specific feature to Albania regarding this topic. Bioethics and Medical Ethics were developed only after the year 1990, when the social system changed after a long isolation period. This corresponded with the start of an open religious practice, including Islam. The majority of the Albanian people recommenced to practice and develop their religions only after 1990, because before this period the communist regime had totally forbidden the practice of religion.

Under these circumstances, I, as a regular researcher of Bioethics and Medical Ethics with over 30 years of experience, maybe with a forensic medicine spirit, since I am at the same time a forensic doctor, very often asked myself if there was a relationship between Bioethics and religion, especially Islam, as the majority of Albanian people practice this religion.

In this forum ( $6^{\text {th }}$ Southeast European Bioethics Forum, Belgrade 2010), I want to introduce some preliminary information of a study that I have done recently concerning this issue.

First, I want to present some information about the attitude of Islam on some fundamental issues of Bioethics and Medical Ethics, and some concise data of Albanian Bioethics and Medical Ethics, followed by a comparison between them. 


\section{The Attitude of Islam regarding some fundamental issues of bioethics and medical ethics}

Aspects of Bioethics and Medical Ethics covered by Islam are termed Islamic Bioethics because the fundamental lesson emphasizes prevention and teaches that the patient must be treated with respect and compassion. The physical, mental and spiritual dimensions of the illness experience must be taken into account (5).

The four main concerns of Islamic Ethics are similar to that of other ethical systems: autonomy, beneficence, non maleficence, and justice. In distinction to western secular ethics, more emphasis is placed on beneficence over autonomy.

These aspects are given in Shariah (Islamic Law), which itself is based on two foundations: the Quran (the holy book of all Muslims, the words of Allah transmitted to Muhamed, and it is considered as the primarily element of the Islamic civilization, also it is "a healing and a mercy to those who believe", and the Sunna (the aspects of Islamic Law based on Prophet Muhammad's words or acts). The Islamic jurisprudence has two other sources: ijmaa (consensus) and qiyas (analogy), resulting in four major schools of jurisprudence (7).

At the same time, because the Quran is seen as eternal and immutable truth, the principles of the law are seen as immutable. Nevertheless, as the circumstances of the day change, the interpretation of the law changes with each age. Islamic law (Shariah), then is in spirit dynamic and flexible, exemplified by the idea that "necessity renders the prohibited permissible" (7).

So, in Islam, the determination of valid religious practice, and hence the resolution of bioethical issues, is left to qualified scholars of religious law.

To respond to new medical technology, Islamic jurists, informed by technical experts, have regular conferences where emerging issues are explored and consensus is sought, for example about organ transplantation, brain death, assisted conception etc.

On the other hand, Islam is not monolithic and a diversity of views in bioethical matters does exist. So, in Canada, some Muslims communities from Central and Eastern Europe and East Africa are more liberal than more conservative communities from Pakistan or some other Middle Eastern countries (7).

Let us explore some of the attitudes of Islam concerning aspects of Bioethics and Medical Ethics.

\section{- The medical confidentiality}

The principle to maintain patient confidentiality is considered of the highest value to a Muslim physician. In Islam, when a patient reaches the age of maturity, the physician is not obligated to reveal any matters that the patient has confided in him to his parent or anyone else (8).

Regarding this topic, according to Islam, doctors do not have to maintain medical confidentiality in cases when it becomes danger for the others (8).

For example, the case of a bus driver with epileptic crises unknown to his employer but known to his doctor: 
In this case, if the doctor would keep this secret, this attitude would be against the honesty notion that Islam preaches. In fact, God has ordered Muslims to be honest and sincere.

\section{The consent}

According to the principles of Islamic Bioethics, a doctor does not have the right to cure or operate on a patient without his consent (8).

For example, the case of a 60 year old person who has a prostate hypertrophy: The surgeon performs prostatetectomy, also he performs the ligature of ductus deferens, assuming that the sterility in this age is an action with no need of consent.

In fact, this attitude is also against the respective principle of Islamic Bioethics.

Competent medical specialists must perform the treatment or surgery after the patient consent.

Under consent rules, the physician is also obliged to inform the patient.

For example, the case of 38 years old patient who undergoes a surgery of lumbal sympatectomy, because he suffered from blood vessel constriction of lower extremities (endarterits obliterans), and was not informed of the consequences of such surgery. Unfortunately, sexual impotence was the side effect of this surgery and the surgeon that performed the surgery was responsible for it. According to Islamic bioethics, all the necessary information should be presented to the patient prior to the procedure or treatment (informed consent). If this implemented, and a side effect will manifest during the procedure, the medical doctor will not be responsible for the outcome based on the judicial concept of assumption of risk.

\section{Death and autopsy}

Death is considered to have occurred when the soul has left the body, but this exact moment cannot be known with certainty. Death is therefore diagnosed by its physical signs (the cessation of respiration and cardiac activity) (4).

The concept of brain death was accepted by a majority of scholars and jurists at the Third International Conference of Islamic Jurists, in Amman, Jordan, in October 1986. Most, but not all, Islamic countries now accept brain death criteria. In Saudi Arabia, for example, about half of all kidneys for transplantation are derived from cadavers, with the application of brain death criteria (5).

According to the Islamic Bioethics, brain death is defined as follows: "When brain is damaged, and its activities completely cease, brain death is present, even if it is possible for the patient to be kept alive in a vegetative state with artificial respiration and medication even the heart and the liver are functioning. Brain death is indisputably established and is considered irreversible when artificial respiration ceases, spontaneous respiratory efforts ceases with five minutes"(5) .

In connection with the autopsy, since according to Islam, the human body is a noble creature in the eyes of God, he should be respected just as if they continuously live. The autopsy that is inconsistent with this nobility is prohibited. Also prohibited is the 
cremation and mutilation of the body. However, in cases of absolute necessity, i.e. in forensic cases in violent deaths, an autopsy will be allowed. The body of the deceased, according to the Islamic religion is washed, wrapped in a white shroud and buried, usually within 48 to 72 hours (7).

Besides ban on autopsy, Islam also bans the use of certain food products, such as the flesh of a dead animal, blood, pork (7).

\section{Euthanasia}

Euthanasia, defined as intentionally fastening of a patient's death and it is considered murder, thus is not permissible in Islam $(5,7,8)$. This includes using a substance that causes premature death (active euthanasia), withholding treatment (passive euthanasia) or "assisted" suicide.

In connection with this attitude, the Quran (9) writes:

"Whoever kills a person shall be deemed to have killed people as a whole ....". According to the Prophet: "The biggest sin after the denial of God, is to become the cause of the shed blood."

"None among us wants to die because of any bitterness."

"My Lord, if it is preferable to live, please keep me alive, whether it is preferable to die, please let me die."

Euthanasia, which means the action of causing the death of the patient who suffers from an incurable disease and pain, this action that opposes life will not be considered fair. This is because the person has no hope to live, yet not dead, though death with a great opportunity to happen, life is still a reality. In this situation, it may happen that the person due to a miracle can recover. Of course, this is a rare case, but that happened sometimes in the history of medicine, called "cases of miracles" (9).

However, in Islamic Bioethics, there are some occasions when euthanasia may be allowed. For example, when the patient or the person who serves him, refuses treatment that does not bring any improvement conditions or quality of life. Similarly, the withdrawal of medical treatment of a patient with cerebral death, will not be considered a form of euthanasia, and therefore would be considered a permitted act (5).

\section{Human Experimentation}

Human experimentation is accepted and allowed by Islam. This is because, according to Islam, human life is sacred, it should be protected from diseases by all means and possible treatments. But to determine the nature of the disease and efficacy of treatment are needed experiments (7).

These experiments, when are carried to the human body, should fulfill the following conditions (7):

1. Consent of the person subject to experiment.

2. Experiment should not be rewarded.

3. It must be performed by a physician competent and honest. 
4. The physician should have strong reasons to think that the results will be positive for health.

5. The physician must be almost sure that the person subject to this experiment will not suffer any physical, psychological or mental damage.

\section{Organ transplantation}

Islamic Bioethics pays great attention to life and health of human beings, which is expressed in the primary sources of Islam.

The Quran (9) says that "the human being as the most valuable creature in the eyes of God, their life and health should be protected and their body should be respected." Prophet prohibits any action that affects their life or destroys the health of human beings. He advises ill people to be treated by a doctor.

In support of these arguments, Islam allows human organ transplants from Muslim and non- Muslim donors, based on the principle that the need of the living supersede those of the dead.

Xenografts, including porcine organs, are also permissible.

Drawing and transfusing blood and blood products are permissible, both from and to Muslim and non-Muslims.

However, to carry out transplants of human organs and tissues must fulfill the following conditions (6):

1. The need to perform transplant organ or tissue should be determined by a qualified physician with a good moral.

2. The physician should be almost sure that the medical treatment will have a satisfactory result.

3. The organ or tissue will be taken from the corpse of a person whose death is certified by a physician.

4. The authorization of the organ or tissue transplant must be given by the donor, or this consent should be given by his relatives when the donor has not given any statement contrary during his lifetime.

5. No action of transaction should be carried to the organ or tissue, since human being is the most noble creature and occupies a special place in God's eyes, therefore no part of the human body, alive or dead should not be sold.

\section{- Issues of reproduction $(5,7)$}

For Islam, sexual life will be respected only in the context of marriage. Premarital sex is forbidden and abstinence is expected of both boys and girls until time of marriage. Because dating is not permitted, Muslims tend to marry earlier than in Western societies. Adolescent marriages are permissible, but less and less common, because of 
increase of higher education for girls. The average age for marriage for girls in most Islamic countries is between 19 and 22

\section{Birth-control $(5,7)$}

Birth-control is permitted by Islam because sex in married couples is considered to be a wholesome pleasure. This view is explained by the argument that if for some reason, parents can not provide for children a good education, they may have a number of limited children, or they can have children not at all, since the purpose of marriage is not just making children, but that the couple have a life to give love and pleasure to each-other. In fact this view is contrary to Christian religion in which sexual relations between spouses without the reproduction intention, have blamed, because in this case, it is violated the sacred nature rule.

\section{Sterilization $(5,7)$}

Islam prohibits any kind of sterilization, because it stops forever the ability to reproduce a human being (sterilization for the purpose of contraception).

However, when there are important reasons for women because the pregnancy may cause her death or dangers her life, in these cases, her sterilization is permitted (therapeutic sterilization).

\section{Abortion (5,7)}

When husband and wife do not want to have children for various reasons, e.g. fear that a parent's illness may be transmitted to children, economic difficulties, illness of the woman, etc. then it can be used contraceptive methods to prevent unwanted pregnancies. While abortion, after the attitude of some representatives of Islam is forbidden, considering it as a crime, if there is no medical reason to do it. But this performance can be allowed if the mother is ill and when this disease no doubt danger her life.

However, there are views that allow abortion.

The general Islamic view is that although there is some form of life after conception, full human life with its attendant rights, begins after the ensoulment of the fetus. Most Muslims scholars agree that ensoulment occurs at about 120 days (4 lunar months plus 10 days) after conception; other scholars, perhaps in the minority hold that is occurs at about 40 days after conception. So abortion has been allowed after implantation and before ensoulment in cases in which there were adequate juridical or medical reasons. Accepted reasons have included rape. Abortion after ensoulment is strictly forbidden by all authorities, but most of Islamic scholars do make an exception to preserve the mother's life. If a choice has to be made to save either fetus or the mother, but not both, then the mother's life would take precedence. She is as a root, the fetus as an offshoot. 


\section{In Vitro Fertilization (babies eprouvette) (7)}

This procedure means that if the woman can not remain pregnant with normal street, her eggs can be placed in a test tube with the sperm of her husband. After fertilization, the embryo must be inserted into the womb of the woman, and takes place there. Islam for this procedure requires that the following conditions are fulfilled:

1. Ova and sperm must belong to a legally married couple.

2. Man or woman must be affected by an illness or disability that prevents them from having a child naturally.

3. Husband and wife should both want to use this method.

4. Medical authorities must be convinced that the birth of a child with this method will not have harmful effects on natural character, psychological and mental health on the parents and child.

According to the surrogacy, after the Shariah, the birth mother, not the ovum donor, would be the legal mother. Surrogacy is therefore excluded.

\section{- Torture (7)}

Islam prohibits torture against a person or animal.

The Prophet said:

"God will surely punish Day, anyone who would have tortured a human being down here."

"I would punish the woman who has left a cat trapped in house without food until it dies."

"Any man who threatens to injure his brother, although he is brother with the same father and mother, will be cursed by angels till he should stop this menace." So Islam forbids any kind of cruelty (savagery) or torture that harms the body or soul, or that causes suffering or distress.

\section{Summary of data on bioethics and medical ethics in Albania}

These disciplines were almost unknown in Albania prior to 1990 and only began to develop after this period using as a model western countries while respecting the medical/religious tradition of our country.

The main source of Bioethics and Medical Ethics in Albania is the medical legislation that emerged after 1990. Thorough studies of aspects of bioethics and medical ethics are detailed in textbooks and numerous other publications available to medical school students of our country. Likewise, Albanian doctors are made aware of bioethics and medical ethics aspects by the New Order of Doctors institution with the goal of implementation of ethical practice of medical profession in our country $(2,3,4)$.

Some of the main aspects of Bioethics and Medical Ethics in Albania are related to (4): 

tance

- several principles, where patient confidentiality and consent are of impor-

- aspects surrounding end of life and death which comprises criteria of death determination, cerebral death, autopsy, euthanasia, etc.

- ethical aspects of human experimentation and transplantation of human organs and tissues.

- ethical issues surrounding genetics and reproduction that encompass sterilization, abortion and in vitro fertilization etc. ethics.

- torture, a form of infringement of human rights, is considered part of bio-

\section{Confrontation of Albanian bioethics and medical ethics with traditional teaching}

The emerging relevant question is whether bioethics and medical ethics developed using western countries as models observe the traditional Islamic teachings given the fact that the majority of the Albanian population affiliates with Islam?

Perhaps some difficulties that are encountered in the implementation of medical ethics during the practice of medical profession in our country, are related or not to the absence of properly reflecting of Islamic bioethics in the legislation?

In order to answer these questions, let us confront the main aspects of Islamic teachings with Albanian Bioethics and Medical Ethics.

It is immediately evident that they are very similar:

- The stance towards medical secrecy (rules and cases when it should not be observed). The concept of consent that is studied and implemented in our country is almost identical to those of Islamic Bioethics.

- Death related aspects such as the criteria for death determination, brain death criteria examined in our country are similar with the positions of Islamic bioethics.

- Laws that prohibit euthanasia in our country are the same as Islamic teachings. For example, both Islamic bioethics and current Albanian euthanasia laws permit passive euthanasia in cases when a patient has lost all consciousness and there is no hope for recovery.

- The attitude towards ethical issues related to human experimentation expressed in Albanian legislation is identical to Islamic bioethics.

- The attitudes toward transplantation of tissues and organs are also similar. In Albanian legislation, law on organ transplantation (1977) emphasized the prohibition of sale of transplants as well as any activity that promotes the advertising, marketing and trafficking of illicit transplants (Article 4), attitude shared by Islamic bioethics. 
- The positions of bioethics and medical ethics in Albania are very similar to those of Islamic bioethics even concerning problems related to reproduction, birth control, in vitro fertilization, abortion, torture.

However, there are a few differences between them especially regarding autopsies. For example, according to autopsy laws of our country (1994), autopsy must be performed in cases where death occurs at a hospital and forensic cases. However, autopsies in case of hospital deaths have not been carried out for over 20 years. Perhaps, Islam in our country that generally prohibits autopsies influenced such interruption.

Furthermore, differences between Islam ethics and Albanian autopsy law are also evident in articles concerning proper burial. According to the law, burial must be performed 12 up to 24 hours after death (4), while Islam bioethics demand that burial must occur 48 up to 72 hours after death.

In addition, surrogate maternity, accepted by our legislation in the law on reproductive health (4), is not permitted by Islamic bioethics.

\section{Conclusion}

From the presentation and discussion of the above data, it should be noted that in the Medical Ethics and Bioethics studied and implemented in Albania, the bioethical thought is very important for the respecting of human rights.

These disciplines developed in Albania using as a model western countries, are very similar with the ideas of traditional Islamic teaching.

\section{Referents}

1 Berna Arda, Vardit Ripler, Islam and Bioethics, Ankara 2011

2 Çipi B., Ethics committees in Albania, Ethics committees in Central and Eastern Europe, J. Glasa, Bratislava 2000, 155-160

3 Çipi B., Bioethics in Albania in a Legal Medicine view, Bioethics and cultural plurality: The southeast European Perspective, 2005, 268-275

4 Çipi B., Bioethics in a Forensic Medicine point of view, Tirana 2005

5 Daar A.S., Khitany A., Islamic Bioethics, Canadian Meidicla Association or its licensor, January 9, 2001, 164 (1)

6 Fetavay-1 Hindiye, 2/390, Ankara, 3.3.1980

7 Keskin A., Analyse des fiches representatives des problemes qui se posent au medecin dans l'exercicse de ses functions du point de vue islamique, Conseil de l'Europe, Le medecin face aux droits de l'homme, 1473-1485

8 Keskin A., Inventaire des texts relatifs a la morale musulmane, Conseil de l'Europe, Le medecin face aux droits de l'homme, 1247-1261

9 Kur'ani, Përkthim me komentim në gjuhën shqipe, Prishtinë, 1987

10 Medical Ethics today: its practice and philosophy, London 1995 